\title{
Brief Analysis of Personality Shaping of Young Teachers of Ideological and Political Course--Analysis from the Perspective of Professional Self-identity and Vocational Happiness
}

\author{
Cheng Yan \\ Electric Power Occupational Technical Institute of Shanxi, Taiyuan Shanxi, 030021, China
}

Keywords: Professional self-identity, Vocational happiness, Personality.

\begin{abstract}
For this paper, survey was made on teachers of ideological and political course of some universities in Shanxi province, and researched was made on the professional self-identity and vocational happiness of teachers of ideological and political course based on considerations about career and realistic society. On this basis, the writer has put forward some opinions on personality reshaping of teachers of ideological and political course.
\end{abstract}

\section{Introduction}

The writer has collected and studied about 60 academic papers on professional self-identity and vocational happiness of teachers in universities published in recent three years, finding most of the papers are on the analysis of reason for the lack of professional self-identity and vocational happiness and of countermeasures therefor, and some of the papers are even of provincial-level key research projects. The records show that there are few researches on the correlation between the professional self-identity and vocational happiness of young teachers of ideological and political course and personality shaping.

Besides, the writer conducted questionnaire survey and in-depth interview on professional self-identity over teachers of ideological and political course at Electric Power Occupational Technical Institute of SEPC, Engineering College of Shanxi University, Taiyuan Electric Power Technical College, and Shanxi Engineering Vocational College, and found that $46 \%$ of the respondents lacked the sense of working fulfillment, $32 \%$ of the respondents considered that it was more promising if they acted as teachers of professional courses or entered the training industry, and $61 \%$ respondents regarded that they just worked for a living. These figures suggest that some teachers of ideological and political course are not enthusiastic for and satisfied with their job too much, and have weak professional self-identity.

It should be noticed that the proportion of young teachers at the aforementioned schools reaches above $50 \%$. In other words, half of the teachers who publicize and implement the advanced theories of the CCP and help students shape the soul are not much older than the students. It is widely recognized that teachers are a model for others. Teachers' every word and action in classroom teaching have a huge effect on students, especially teachers of ideological and political course. Thus, we can imagine what influence will be made on students, the society and the country if a teacher who disagrees with the theories of the CCP and the society, and has anti-Party and anti-social words and behaviors presents in the classroom. Hence, it appears to be urgent to study the influence of professional self-identity and vocational happiness on young teachers of ideological and political course, which will influence teachers' personality. 


\section{Connotation of Professional Self-identity and Vocational Happiness of Teachers of Ideological and Political Course}

\section{Connotation of Professional Self-identity and Vocational Happiness}

\section{Professional Self-identity}

Professional self-identity is commonly defined to be that an individual's viewpoint on the objectives, social value and other factors of a career is consistent with social evaluation and expectation on the career, namely that an individual completely agrees or accepts the viewpoint and understanding of a career by other people or groups [2][3] [4].

Vocational Happiness

Vocational happiness refers to the continuous experience of happiness obtained by an individual for his/her needs are satisfied, potential is tapped, or value is reflected while performing some work [5] [6].

The professional self-identity and vocational happiness of young teachers of ideological and political course at universities have a huge effect on the development of teaching, their career planning and their whole life.

\section{Professional Self-identity of Teachers of Ideological and Political Course}

Based on the concept of professional self-identity, the writer has the following viewpoints on the professional self-identity of teachers of ideological and political course.

Firstly, it is about national identity of teachers of ideological and political course.

National identity is a political concept, referring to cognition of a citizen about which country he/she belongs to and his/her assessment and feeling about the composition of the country, such as politics, culture, ethnic group, and such factors [7].

Teachers of ideological and political course must realize that a qualified teacher of ideological and political course should be with excellent political accomplishment, of which the basis is national identity. National identity is highly consistent with the content of ideological and political course and the "three outlooks" of teachers of ideological and political course.

Secondly, it is about theoretical identification of teachers of ideological and political course.

Over the past 500 years, socialism had experienced from fantasy to science, and from theory to practice, and our predecessors had worked out scientific guiding ideology by linking theory with practice, namely Marxism-Leninism, and the outcomes of combining Marxism-Leninism with China's reality, including Mao Zedong Thought, Deng Xiaoping Theory, the important thought of "three-represents", and the Scientific Outlook on Development. This set of theories have been prevailing until now and being used to guide practice, which reflects the tremendous vitality of the theories and indicates that the theories are incomparable in respect of scientificity.

The contents of ideological and political course decide that teachers of ideological and political course should aim to arm college students with the theoretical system of socialism with Chinese characteristics, guide various social thoughts with socialist core value system, and cultivate students into all-around developed socialist builders and successors.

Thirdly, it is about recognition of teachers of ideological and political course about the role of ideological and political course.

Teachers of ideological and political course of universities are an important force of teaching body of institution of higher learning, who do not only shoulder the task of transmitting positive energy, but also undertake sacred historic responsibility. Their responsibility is to publicize the theories, line, policies, and guidelines of the CCP in classroom teaching, and guide and lead college students to develop and group in a healthy way. Although the teaching of ideological and political course doesn't necessarily get effect instantly, it is highly possible that a word or viewpoint of a teacher will influence students' value orientation and even change students' whole life. This is because that what teachers of ideological and political course impart is not only knowledge, but also consciousness and ideas.

Most young teachers get well along with students like "old brother" or "old sister". It is because of this that students are willing to accept teachers' viewpoints. Hence, young teachers, as the mainstay of 
the teaching body of ideological and political course, should acutely realize the important role of this course in guiding students' to form right "three outlooks", practice the socialist core values, and choose the path of life. This must be realized.

Teachers of ideological and political course are such a special group among the teaching body that their professional self-identity can directly influence the teaching effect, the correct propagation and implementation of the core values, and even social security and stability.

\section{Vocational Happiness of Teachers of Ideological and Political Course}

The writer, through the survey over the schools, found that the respondents had high vocational happiness on the whole. But there were also some teachers tired of the vocation, especially young teachers who are faced with heavy teaching load, large pressure of professional title promotion, limited promotion opportunity, and heavy living burden. Thus, many young teachers are seldom satisfied with and tired of their job.

Firstly, teaching practice is a way to realize happiness.

Initially, most young teachers can fulfill the assigned teaching tasks with quality and quantity guaranteed, have a clear understanding of the teaching idea, are proficient in various teaching skills, and can achieve excellent teaching effect. At the schools surveyed, the class hour per week of a young teacher can reach 10 to 12 class hours. To put it other way, a young teachers can repeat the same contents 5 to 6 times. Thus, their feeling of freshness has gradually disappeared in the process of repeating the tedious job, and the challenge has gradually become mechanical work for them.

The unity of "knowledge and practice" suggests the right or wrong in professional courses, while can reflect the attainment of an individual and even a nation in ideological and political course. It is really not easy to feel happy in the teaching process of ideological and political course, and teachers can feel happy when they impart the knowledge engraved on their memory to students and get positive response or eye contact of cognition from students or students resonate in discussions only. This verifies that, as insisted by $С$ у х о м л и' н с к и й, education is not repetition, but creation.

In the teaching process, young teachers' professional self-identity also gets recognized by students. Only in this way, teachers' personality charm formed based on professional self-identity can infect, guide and inspire students, which is a process of self-identity sublimating into happiness. The process of sublimation proceeds via teaching practice.

Secondly, happiness comes from students.

Teachers' vocational happiness is related to their physical state, interpersonal relationship, motivation, and job content. But teachers can obtain higher happiness if they are satisfied and resonate spiritually.

As discussed above, we can know that the carrier of happiness of teachers of ideological and political course is teaching practice, and teachers' happiness directly come from students. We often regard that ideological and political course is different from professional courses, which usually relates to viewpoint discussion, exchange of thoughts and soul collision. Students' behaviors and words in class, out of class and even in social environment decide whether teachers of ideological and political course can feel happy. As an old saying goes, "teachers are to pass their knowledge". It is the greatest happiness for teachers of ideological and political course to impart, publicize and implement the course contents in class, make spiritual communication and share happiness and joy with students after class, help students relieve themselves from frustration and bewilderment, and guide students to learn theoretical knowledge of socialism with Chinese characteristics, form correct "three outlooks", become a useful person to the society, and shoulder the key mission of constructing a socialist country with Chinese characteristics in different positions. 


\section{Correlation between Professional Self-identity and Vocational Happiness}

\section{Professional self-identity is the premise of vocational happiness.}

Professional self-identity is important for both teachers and schools, which will not only have an effect on teachers' vocational happiness, but also is the key to whether the teaching objectives of a school can be realized. The premise for whether a teacher can put his/her heart into teaching must be that he/she accepts and favors his/her job from the heart. Once a teacher has formed professional self-identity, his/her initiative and enthusiasm can be stimulated easier, which will be transformed into motivation, and is helpful to alleviate and even eliminate job burnout sense. As long as a teacher has formed professional self-identity, he/she is sure to input more time and energy in class preparation, teaching, and other teaching activities [8].

Hence, teachers' professional self-identity is the premise for their vocational happiness. Teachers can enjoy their job of teaching only when they can get satisfied in this job, and develop high professional enthusiasm and professional self-identity.

\section{Vocational happiness is the sublimation of professional self-identity.}

Happiness is a state when the physiological or psychological needs are satisfied. Researches show that "the happiness index of teachers is significantly associated with the factors of professional self-identity and the total level of professional self-identity of teachers" [9]. This will not be repeated below.

\section{Correlation between Personality Shaping of Young Teachers of Ideological and Political Course and Self-identity and Happiness}

Fang Mei, a national excellent teacher of ideological and political course, has proved, via his own actions, that a teacher of ideological and political course who "is proficient in, believes in, devotes himself to, and loves his career" can infect students. Fang Mei has showed us the effect of professional self-identity on students and teaching. For teachers of ideological and political course, personality charm has a more direct influence on students' enthusiasm, coherence, and radiation than for teachers of other courses. Thus, it is of great importance for young teachers of ideological and political course to shape personality charm, impart course, and publicize and implement thoughts and make exchange in a better way, to make students favor and benefit from ideological and political course.

\section{Professional self-identity is the basis for personality shaping of young teachers of ideological and political course.}

Young teachers of ideological and political course should adhere to correct guidance of public opinion and hold a mature political stand; have a clear and correct idea on some major issues, such as construction of the theory of socialism with Chinese characteristics, aim of life, value of life, and meaning of life; and have a unique opinion on and master dialectic handling method of hot spots and doubtful points of society, so as to be able to influence, impel and inspire students in class and life. In view of this, professional self-identity provides a solid theoretical foundation for young teachers to shape a perfect personality.

\section{It is a process of internalization to sublimating professional self-identity into vocational happiness.}

In the traditional process of teaching and learning, students usually regard teachers with reverence, which is the reflection of respecting teacher and his teaching. But what helps teacher conquer students is not his stateliness but his morality, knowledge and other non-authority qualities, which urges young teachers to constantly expand their scope of knowledge and improve themselves in various aspects while aiming to achieve teaching effect. In this process, young teachers can raise their value, get improved, and internalize the theories, to become the biggest and most direct beneficiary. 


\section{The personality charm of young teachers of ideological and political course comes from self-identity and the sense of happiness.}

Presently, the personality charm of young teachers of ideological and political course is mainly reflected by flexible teaching method, various teaching means and impressive expression. Some young teachers fail to show impressive personality charm due to the lack of professional self-identity and vocational happiness for some reasons. As Ushinsky, who was praised as the "teacher of Russian teachers", said: "everything of education is based on teacher's personality, because the power of education only comes from alive personality, only personality can influence the formation and development of personality, and personality is formed only based on personality. [10]" Teachers' personality charm is an important type of education resources, and also an imperceptible education force.

Teachers' personality charm comes from their erudition and solid foundation, and their enthusiasm and passion for their job. In a sense, we can interpret the two elements into the self-identity and sense of happiness of teacher.

Young teachers of ideological and political course should hold a noble belief in the Marxism-Leninism, build a dream consistent with social development, and shoulder the important mission as a teacher of ideological and political course. Only by internalizing the "self-identity" and enjoying the "happiness", they can constantly tolerate, accept, exceed, and perfect themselves, to infect students with their personality charm.

\section{References}

[1] Сухомли' н с к и й, 100 Suggestions to Teachers, Tianjin: Tianjin Peoples Publishing House, 1981.

[2] Wang Xinqiang, Zhang Dajun, Xue Zhonghua, Qi Xiaodong, et al. Correlation between Professional Self-identity of Normal University Students and the Meaning of Life, Psychological Exploration,2012,32(3):277-281.

[3] Long Qiulin, Liu Jing. Current Situation of Professional Self-identity of Instructors of Higher Vocational Colleges and Improvement Measures therefor, Journal of Heilongjiang Vocational Institute of Ecological Engineering, 2007.1

[4] Xie Peisong, "Professionalization": Core of the Innovation of Teacher Education, Journal of Changsha Railway University (Social Science), 2006(12).

[5] Hui Zeyu, Research on National Selfhoodness and National Civility, Master's Thesis of Minzu University of China, 2010(9).

[6] Zhou Dong, Research on Vocational Happiness of Young Teachers of Higher Vocational Colleges, Social Sciences Review, 2012, 3.

[7] Qin Cailuan, National Identity of Zhuang People and the Stability in Border Areas-Research on "Four Models" of National Minorities in Guangxi II, Guangxi Minzu Yanjiu, 2010.

[8] Qu Guangyong, On Professional Self-identity of Teachers of Universities and Influence Factors thereof, Journal of Mudanjiang College of Education, 2013(03).

[9] Yu Songhua, Research on Correlation between Happiness Index of Teacher and Professional Self-identity and Social Support, The Science Education Article Collects, 2009(11) (last ten-day).

[10]Luo Wei, Research on Ability and Accomplishment Required for Professionalization of Chinese Teacher, Policy \& Scientific Consult,2009 (11). 